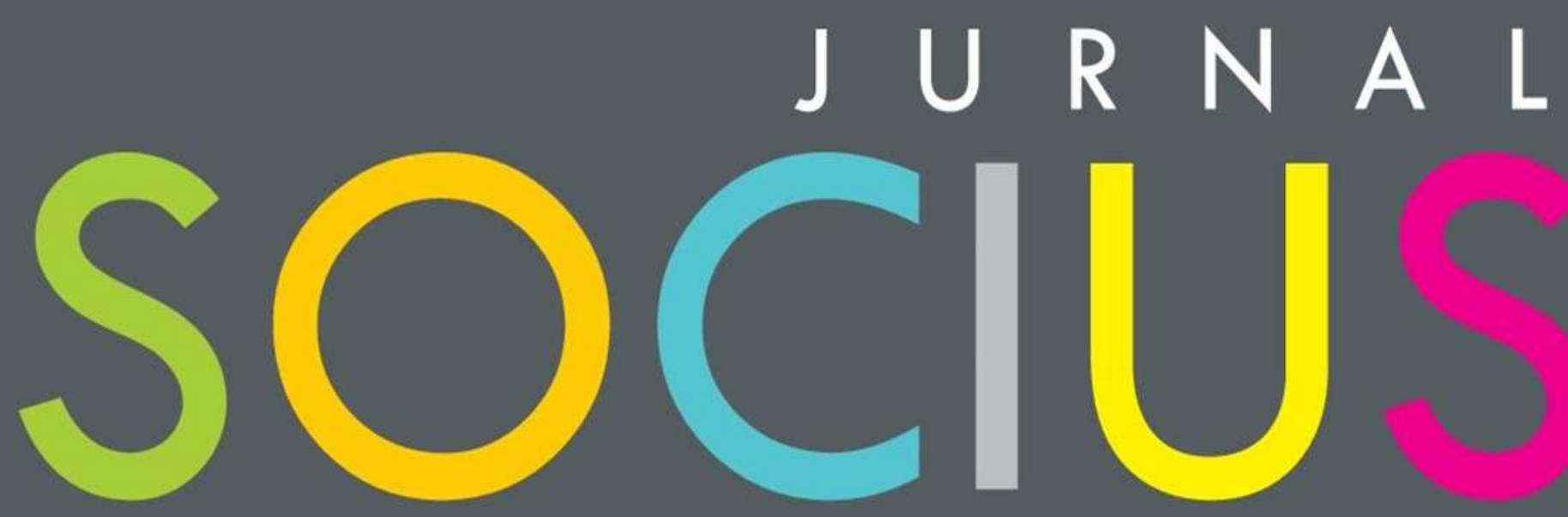

Journal of Sociology Research and Education

DITERBITKAN OLEH :

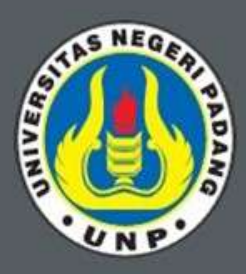

$\angle A B O R$

JURUSAN SOSIOLOGI FAKULTAS ILMU SOSIAL UNIVERSITAS NEGERI PADANG

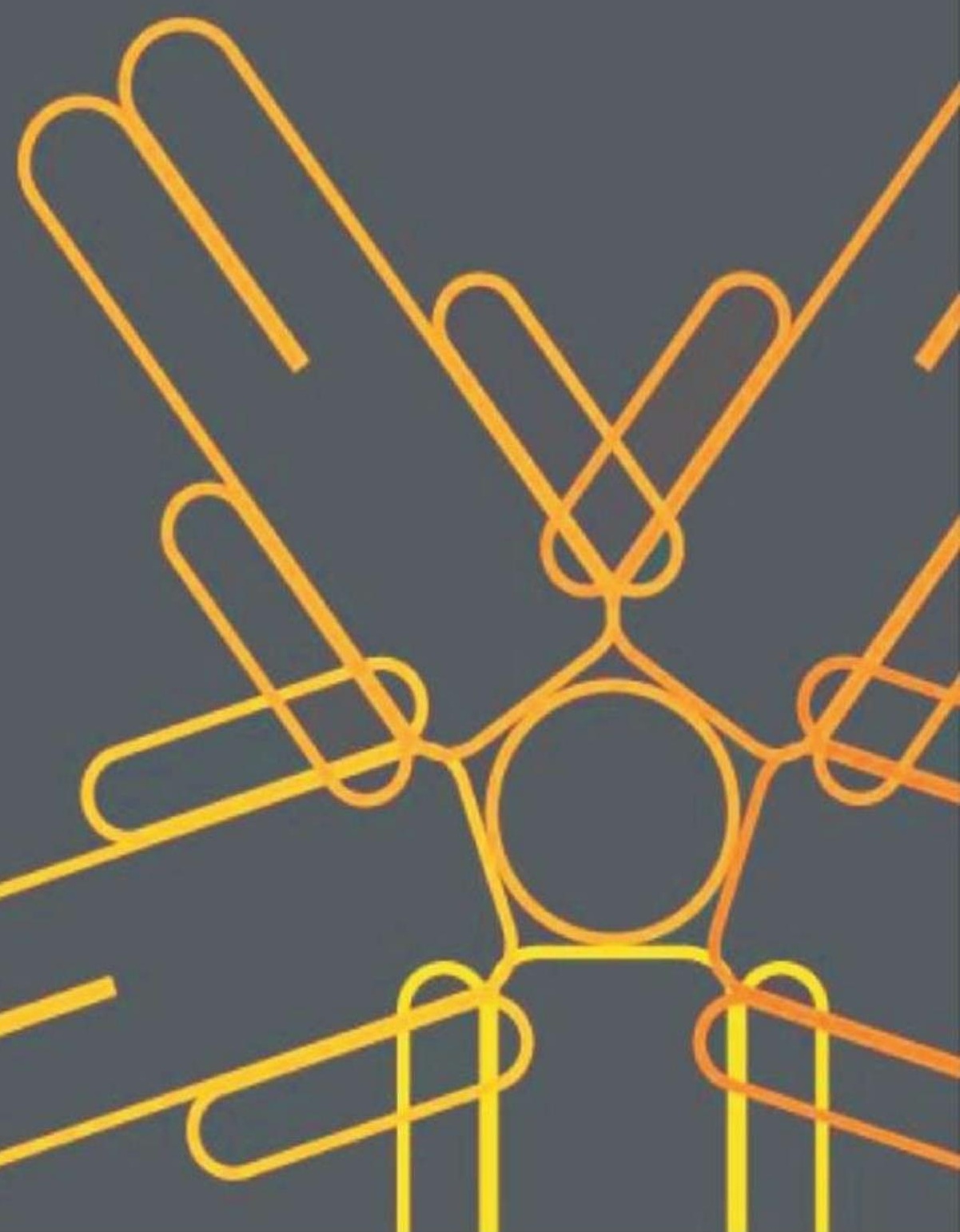




\section{SOCIUS}

Vol. 7, No. 2, Th. 2020

ISSN : 2356-4180 (cetak)

2442-8663 (online)

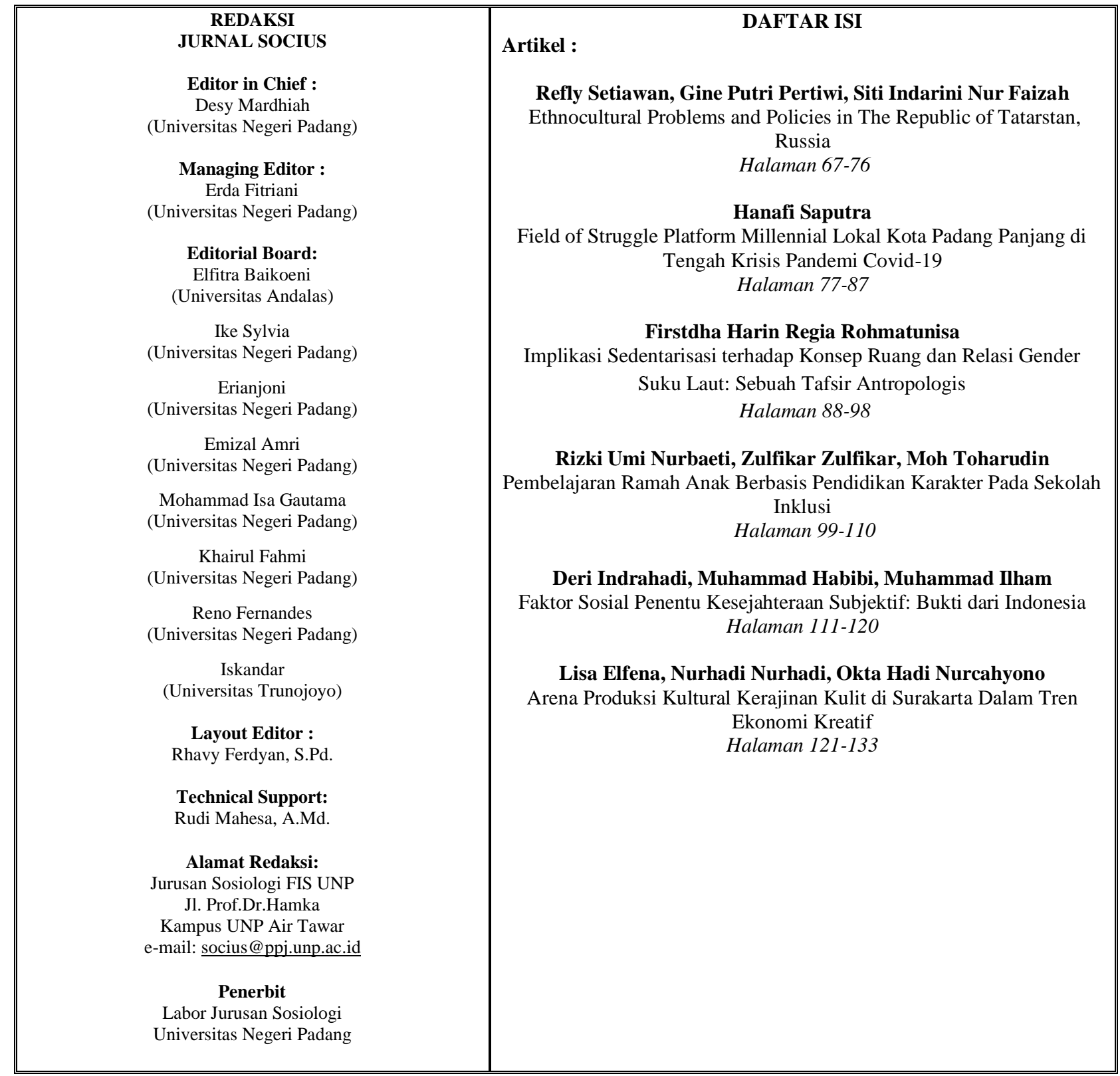




\title{
Ethnocultural Problems and Policies in The Republic of Tatarstan, Russia
}

\author{
Refly Setiawan', Gine Putri Pertiwi², Siti Indarini Nur Faizah ${ }^{3}$ \\ 1,2,3Kazan Federal University, Russia

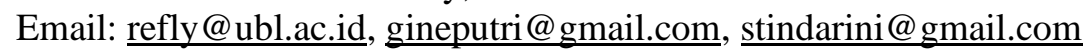

\begin{abstract}
Abstrak
Penelitian ini membahas mengenai masalah dan kebijakan etnokultural di Republik Tatarstan, Rusia dengan populasi multietnis yang kompleks dalam kondisi keseimbangan antara dua suku bangsa utama, yaitu Rusia dan Tatar. Selain itu, terdapat pandangan historis dan ideologis untuk pembentukan kebijakan etnokultural di Tatarstan, tren positif dan negatif di bidang hubungan antaretnis. Penulis menitikberatkan pada aspek implementasi kebijakan etnokultural seperti implementasi hak untuk menerima pendidikan etnokultural dan pelestarian bahasa asli, dukungan terhadap budaya masyarakat lokal, interaksi dengan asosiasi etnis masyarakat, dan lain sebagainya. Selain itu juga melihat bagaimana legislatif. dan kerangka peraturan diterapkan di bidang kebijakan etnokultural. Hasil penelitian ini menggambarkan bahwa adanya situasi di bidang relasi antaretnis yang dapat menunjukkan berakhirnya model kebijakan etnosentris di daerah yang berpihak pada masyarakat Tatar dalam kondisi multikulturalisme saat ini. Dalam hal ini ada orang atau kelompok yang merasa tidak puas di kedua sisi kebijakan yang diambil sehingga kepentingan kelompok etnis lain di wilayah tersebut juga kurang mendapat perhatian seperti: Chuvash, Mordovia, Mari, Armenia, dan lain sebagainya. Hal ini dapat berujung pada radikalisasi kelompok etnis tersebut.
\end{abstract}

\section{Kata kunci: Etnis minoritas, Identitas etnokultural, Kebijakan etnokultural, Masalah etnokultural, Multikulturalisme, Proses etnopolitik, Republic of Tatarstan}

\begin{abstract}
This study discusses about ethnocultural problems and policies in the Republic of Tatarstan, Russia with a complex multiethnic population in a condition of balance between the two main ethnic groups, namely Russians and Tatars. In addition, there are historical and ideological views for ethnocultural policy formation in Tatarstan, positive and negative trends in the field of interethnic relations. The author focuses on aspects of ethnocultural policy implementation such as the implementation of the right to receive ethnocultural education and preservation of indigenous languages, support for traditional folk culture, interaction with public ethnic associations, etc. In addition, it also looks at how the legislative and regulatory framework is applied in the ethnocultural policy area. The results of this study illustrate that the existence of a situation in the field of inter-ethnic relations can indicate the end of the ethnocentric policy model in areas that are in favor of the Tatar community in the current conditions of multiculturalism. In this case there are people or groups who feel dissatisfied on both sides of the policies taken so that the interests of other ethnic groups in the region also receive less attention, such as: Chuvash, Mordovia, Mari, Armenian, etc. This can lead to the radicalization of these ethnic groups.

Keyword: Ethnocultural problems, Ethnocultural policy, Ethnopolitical process, Ethnic minorities, Ethnocultural identity, Multiculturalism, Republic of Tatarstan

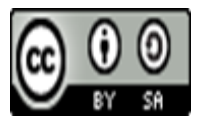

Received: October 8, 2020

Revised: October 25, 2020

Available Online: December 21, 2020

Jurnal Socius: Journal of Sociology Research and Education Vol. 7, No.2, Th. 2020

ISSN: Online 2442-8663 - Print 2356-4180

Copyright $\bigcirc 2020$, Jurnal Socius 


\section{Introduction}

The Republic of Tatarstan is an ethnic republic within the Russian Federation, therefore it is a model of ethnocultural policy in a region dominated by a non-Russian population. In addition, Tatarstan consistently defends its right to sovereignty (which was also substantiated by the ethnic aspect), the right to implement its own language policy, in particular the right to choose the alphabet for the Tatar language, and seeks to use ethnic resource when interacting with the federal center. The Republic of Tatarstan is a multi-ethnic territory, the composition of which is determined by the main groups namely Tatars and Russians, as well as representatives of ethnic minorities. The latter are represented by indigenous peoples in the Volga-Ural region: Chuvash, Mari, Mordovia, Udmurts, Bashkirs and Ukrainians, Germans, Jews, Armenians, Azerbaijanis and other peoples who recently settled in the region. Currently, the most ethnic groups in the region are: Tatars at $52.9 \%$ of the population, Russians at $39.5 \%$ of the population, Chuvash as much as $3.3 \%$ of the population, Mordovia as much as $0.6 \%$ of the population, Udmurts at $0.6 \%$ population, Ukraine $0.6 \%$ population, Bashkirs $0.4 \%$, Kryashens $0.5 \%$, Mari $0.5 \%$, Azerbaijan $0.3 \%$, Belarus $0.2 \%$ population, Germany as much as $0.1 \%$ of the population, Armenians as much as $0.1 \%$ of the population, Jews as much as $0.1 \%$ of the population, Tajiks as much as $0.1 \%$ of the population, and Uzbeks as much as $0.1 \%$ of the population (Sergey, 2020). The rest of society is numerically less than $0.1 \%$, but these people have their own national and cultural center and actively interact with regional authorities. Among this ethnic group are Georgians, Kazakhs, Moldovans. From 1990 to 2000, the number of Tajiks more than quadrupled, the number of Armenians tripled, the Azerbaijan community nearly doubled, and Uzbeks and Georgians increased significantly. Vietnamese, Turkish and representatives from several other countries add to the diversity of multinational Tatarstan (Valeev, 2005).

The modern ethno demographic profile in the Republic of Tatarstan was formed because of the migration process. Tatarstan's economic modernization 1960 to 1980 led to a wave of Russian immigration to the federated republics. In 1990 to 2000 in Tatarstan, against the background of the process of "ethnic magnetism" (that is, the attraction of the ethnic homeland to Tatars) characteristic of the Tatars during this period, there was a significant increase in the Tatar tribe and a decrease in the number of Russians due to intensive immigration. to the Republic of Tatarstan and emigration (Kuznetsov, 2020). In Tatar society, there are ideological and political divisions in the struggle for "true history" between "Tatarists" and "Bulgarists". This split is interesting for this study because it affects the ethnic identification of the Tatar people in the Republic of Tatarstan. Moreover, this struggle began not in the 1990s, but in the mid-19th century (Valeev, 2005), when Tatar intellectuals were actively involved in the historical construction of the Tatar ethnicity, the imagination of the new Tatar (or Bulgarian) ethnic community and nation-building in general. The aim of the Tatar approach is to focus on the issue of the Golden Horde of the modern Tatar tribe which is a consolidation of the culture and language of all the Tatars in Russia under the auspices of the Kazan Tatars. The Tatars also dreamed of a symbolic domination of Russia which, according to their glorious history, allowed them to advance. However, given the history that the early Turkish empire developed long before the emergence of the Kievan Rus and the powerful Golden Horde kept the Russian empire under Tatarstan (Sergey, 2020). The basis of the Bulgarist approach that carries Tatar ancestry from the pre-Mongol Volga Bulgaria is a concern for the territorial integrity and sovereignty of modern Tatarstan. In addition, he tries to rid the Tatars of the negative image that has been forced on them over the centuries by Russian literature accusing them of defeating Kievan Rus. For decades, Tatar scholars have tried to counter this tradition and some 
have seen acceptable solutions in emphasizing the roots of Bulgar thought to Tatar society to changing self-names (Djokic, 2020).

Today we can say that the Bulgarists won victory over the Tatars, but not completely. So, since February 1992, the symbol of the Bulgarian winged leopard has decorated the emblem of the new state of this republic. The celebration of the 1000 th anniversary of the city of Kazan emphasizes the importance of the Bulgarian period in the history of the Kazan Tatars (Izmailov, 2018). But at the same time, the ethnonim remains the same and the history of the Golden Horde and the Kazan Khanate is still remembered. In addition, Tatars are divided into ethnic sub-groups: Kazan Tatars, Siberian Tatars, Astrakhan Tatars, Kryashens, Nagaybaks, and Mishars. The Kryashen consider themselves to be descended from Orthodox Turkic speaking tribes, baptized during the Bulgarian Empire (VI-VIII centuries). The second wave of baptisms dates back to the time after the arrest of Kazan in 1552 (the so-called "baptized parents"), the third wave of which lasted into the second half of the 18th century (the so-called "newly baptized"). Ethnogenesis Kryashens attended by Finno-Ugric, Turkey, including Nogai-Kypchak, and people who have important roles. Kryashen are genetically related to the Kazan Tatars, but they retain the authenticity of the material and spiritual culture, as well as the peculiarities of their language. The Kryashen community has been allocated one of the Kazan churches, Tikhvin, which carries out the function of uniting representatives of this sub-ethnic group. In Tatarstan they are referred to as baptized Tatars, but they do not recognize themselves that way, they want to be called Kryashens. This problem reached a high intensity in the last decades of the 20th century and in connection with the emergence of national movements and the formation of a new national ideology in Tatarstan (Gabdrakhmanova, 2008).

In the run up to the 2002 All-Russia census in the Republic of Tatarstan, questions about the history, peculiarities of Kryashen culture and life, relations with other Tatar groups were actively discussed. At times, the discussion took on a character that was exacerbated and politicized by an overestimation of the threat of the oftenheard Tatar division and activists of the Kryashen ethnocultural organization who often raised questions about Kryashen independence (Valeev, 2005).

This research aims to explain and describe how ethnocultural policies in the Republic of Tatarstan can reduce divisions and conflicts between ethnic groups in the region. This article provides a contribution and novelty to the study of handling problems based on culture in multicultural societies, which have rarely been discussed in previous studies. Meanwhile, ethnocultural policies are considered quite effective in reducing divisions and conflicts in multiethnic communities.

In the Republic of Tatarstan, there are various ethnicities who live side by side and give their own color to the region. Tatarstan actively prevented the separation of the Kryashens and Siberian Tatars into separate groups. The 2002 census identified ten thousand Nagaybaks as separate ethnic categories and now they are not considered Tatars. The Kryashens and Siberians in Tatarstan that were previously unnoticed among the Tatars are now starting to emerge. For similar reasons, in the 2002 census there were no statistically "independent" "Kryashens" and "Siberian Tatars" categories. They are indicated as the Tatar subgroup. And it also causes waves of social and political emotions (Makarov, 2016). The hallmark of Tatarstan is the holding of various congresses, congresses, meetings of both individuals (especially Tatars) and all people living in the Republic of Tatarstan. The Milli Majlis (Tatarstan People's Parliament) held curultais (meetings or congresses) and organized Tatar youth forums. The World Tatar Congress which is the most influential and most effective ethnopolitical organization of the Tatar tribes whose 
decisions are decisive in Tatarstan's internal politics holds its congress every five years (Markov, 2016). Through the congress, it is hoped that it can create a sense of unity and integrity between ethnic groups which can prevent conflicts in the region.

\section{Research Method}

The research method is basically a scientific way of obtaining data for specific purposes and uses. Which is based on scientific characteristics, namely rational, empirical, and systematic (Farida, I., \& Setiawan, 2018). The method used in this research is qualitative research methods. The Qualitative Research Model is rooted in the natural setting as wholeness, relies on humans as a research tool, utilizes qualitative methods, conducts data analysis inductively, directs research objectives towards finding a theory from the ground up, is descriptive in nature, limits the study to focus, has a set of criteria to examine the validity of the data, the research design is provisional, and the results of the research are agreed upon by both parties: the researcher and the research subject (Farida, I., \& Setiawan, R 2018).

In this research, the research design used is descriptive research design. Where in the descriptive research design is carried out to obtain a deep understanding of the situation and the meaning of the subject under study. In this study, the researcher looked more deeply at the ethnocultural policy in the Republic of Tatarstan and reviewed it based on actual facts. Sources of data in this study came from 2 sources, namely primary data and secondary data. Primary data sources are data obtained directly from the object of research which are collected and processed by themselves (Farida, I., Setiawan, 2018). The data needed is data related to ethnocultural policy in the Republic of Tatarstan. While secondary data sources are data sources that are done by reading, studying, quoting, and reviewing literature, archives, articles, documents, and other supporting materials related to the issues to be studied. The instruments used in this research are observation, interview and documentation. Through observation, researchers learn about people's behavior in the Republic of Tatarstan and the meaning of these behaviors. While the interview technique used is in-depth interview, which is the process of obtaining information for research purposes by means of face-to-face question and answer or through electronic connections such as telephone calls between the interviewer and the informant or the person being interviewed, with or without using guidelines (interview guide), where the interviewer and the informant have agreed to conduct the interview. The informants came from figures in the Republic of Tatarstan such as: Head of the Department of Home Affairs in the Government of the President of the Republic of Tatarstan, Cultural Advisory Board in Tatarstan, Observer of Culture in Tatarstan, Member of The Council in The Republic of Tatarstan, Youth and Researcher of Tatar culture.

\section{Results and Discussion}

\section{Regional ethnocultural policy ideologies and principles}

For Tatarstan, there are two important factors in the ideology of inter-ethnic relations: the idea of a Tatar state and efforts to build the nation on the basis of ethnicity; the use of ethnocultural politics as opposed to the federal center. Nation-building determines the relative priorities of Tatar culture in relation to other cultures. In other words, Tatar culture is considered inferior to Russia, and therefore needs priority support. According to Rustam Minikhanov as President of Tatarstan, in the 1990s, the threat of deliberate exacerbation by the republican leadership was used to seek economic and political preferences from the federal center. But gradually it became clear that this was just rhetoric and that the political leadership of Tatarstan would not actually worsen relations, as this was also a threat to the authorities in the region. Only radical nationalist groups that feel 
most comfortable in a conflict environment can agree to worsen inter-ethnic relations. The reason is only a declarative nationalist discourse on the part of the regional authorities, according to Khairullovich Mukhametshin as head of the council of the Republic of Tatarstan stating that in reality the political and regional administrative elites consist of almost $80 \%$ of Tatar peasants. Consequently, conservatism, backsliding, wary of any serious change, serves as psychological pressure for the stagnant authoritarianism of the ruling elite and consistent nationalism (Belyaev, 2007).

The most expressive ideological component of ethnocultural policy was expressed by Mohamed Shamiev as the cultural advisory board in Tatarstan:

"When all information on television and radio is mostly in Russian and it turns out that a child has only heard Russian speech from childhood, work has to be done. is to preserve the Tatar language. As a child, my wife didn't dare to speak Tatar on the street. And when he spoke, he felt disabled. Well, fortunately, this is not the case, the Tatars speak their mother tongue in full voice and not only in Tatarstan. For example, my tongue wouldn't blame the Russian-speaking population for something. No Russian opposes the Tatar language. It is a joyful day that all residents of Tatarstan understand that tolerance and reciprocity are required here. The most dangerous thing that might happen in Russia is the open call for great Russian chauvinism. We value the excellent interethnic relations in this republic, and must not allow anyone to spark interethnic strife. We are equal among equal people and this is the best guide to action for us". (Interview on 6 July 2020).

This was also emphasized by Alexander Terentyev's statement as Head of the Department of Home Affairs in the Government of the President of the Republic of Tatarstan who was responsible for the implementation of ethnocultural policies, which stated that: "Ethnocultural policy in Tatarstan is based on two basic principles:

The need for comprehensive development of the Tatar community. and strengthening the Republic of Tatarstan as a form of state history and ensuring equal conditions for Tatars for all ethnic groups and on the other hand collectively representing multinational people in Tatarstan (Interview on 10 July 2020).

According to Dmitry Nagiev as observer of culture in Tatarstan stated that:

Tatarstan is characterized by a hidden ethnocentrism, where the Tatar culture is in the middle, in a state of multiculturalism is expressed (Interview on 12 July 2020).

Despite the fact that the relative priority of Tatar culture has been established in the region, the leaders of the Tatar community who believe that the Tatars in the republic are discriminated against, they are not allowed to develop their Russian culture and culture and dominate in everything. In the Tatar socio-political environment, there is a certain sense of institutional insecurity from the Tatar language and Tatar culture. Therefore, according to various opposition parties, support for him is very important. Another important idea that gives rise to practical guidelines for official action is that Tatarstan is the only territorial-national entity, the ethnic group that plays a role in Russia is the Tatars therefore only in this region can Tatar culture be supported.

\section{Experience of Ethnic Political History and People's Historical Memories of Their Own Ethnopolitical Situation}

In the history of the Republic of Tatarstan there are no instances of clashes between ethnic groups. Various nations have always coexisted peacefully in this compactly inhabited region. It is 
also important that only a quarter of the Tatars living in the Republic of Tatarstan and the Kazan Tatars are an ethno-territorial group that includes a representative minority of these people. The presence of many relatives throughout the Urals and the Volga region complicates the possibility of conflict on ethnic grounds. The dual ethnic composition of a population consisting of two roughly equal Tatar and Russian communities is not bipolar in terms of the nature of the relationship. There is almost no conflict at the household and production level as well as a very high proportion of inter-ethnic marriages and the normal functioning of mixed collectives which all indicate a deep dispersion of ethnic groups. The Russian-speaking Tatars who make up a quarter of the region's Tatars do not tend to confront the Russian population.

Apart from that, Tatars, Russians and others repeatedly joins forces against common enemies. The wars between them were fought with varying degrees of success and, according to medieval custom, were not violent between ethnic groups, but between state and religion, which determined the political players who would rule (Ilinskaya, 2018). There are many generals, diplomats, aristocrats among the Tatars. Russia and Tatars fought together in the Minin and Pozharsky units to restore the country's national independence, while in the Razin and Pugachev military units they fought alongside the oppressors, as well as in civil war and in World War II. Deep spiritual diffusion occurs when the mentality of Russian and Tatar intellectuals is practically intertwined. This shows that often nationality does not even influence whose ethnic culture a particular creator developed (Andrew, 2015).

On the other hand, Tatar intellectuals and politicians are haunted by the status of Tatar statehood, which was previously achieved as a result of Ivan the Terrible's conquest of the Kazan area and the forced Christianization of Ivan IV and Catherine II (Sergey, 2020). In Tatarstan, the idea of the Volga-Ural Republic was very popular and was proclaimed back in 1917 by Milli Mejlis of Tatarstan, who worked in Kazan, and on March 23, 1918 by the liquidated Soviet government. Moreover, Bulgaria's Volga region, Golden Horde and Kazan Khanate are undoubtedly in the public domain. The personality of Kul Sharif, the imam of the Kazan mosque, poet and educator of his time, is an example for society. According to Daniel Ivanovich as a youth and researcher of Tatar culture said that:

Its strength lies in the fact that it defends the freedom of the Kazan Khanate from the invaders at Ivan the Terrible. The construction of a mosque in the Kazan Kremlin architectural ensemble immortalizes this imam's name in history (Interview on 15 July 2020).

\section{Legislative Support for Regional Ethnocultural Policies}

The concept of National Policy for the State of the Republic of Tatarstan applies in the Republic of Tatarstan. According to the plan, based on this concept, a national policy implementation program for the Republic of Tatarstan will be developed (Sergey, 2020). However, it hasn't been developed yet. The concept implementation program has actually been developed at the city level. The leadership of the republic has delegated the task of implementing ethnocultural policies to the local level. This approach is considered to be justified in the conditions where the ethnic groups live together. Legislative support for ethnocultural policies in the Republic of Tatarstan has actually recently been developed. It can be said that the regional regulations in this area are scattered, namely. scattered in various regulations. Currently, the Republic of Tatarstan has a law "Regarding national and cultural autonomy in the Republic of Tatarstan", which in fact simply mimics a similar federal statute. According to the laws of the republic, cultural-national autonomy is entitled to receive the support of the Tatarstan state authorities and local self- 
governing bodies, which are necessary to preserve their national identity, develop indigenous languages and national culture. In addition, it is planned to finance national and cultural autonomy activities in the regions at the expense of the republic's budget (Zubarevich, 2018).

Among other normative acts, one can choose the "Law of Education" in the Arts. 5 Tatarstan's law covers the right to receive a national education, but the true content of education is not disclosed. In addition, this law regulates the possibility of obtaining education in the mother tongue, but special status is given to the two national languages, namely Tatar and Russian (Dolzhikova \& Moseykina, 2020). Russian law "On Culture" traces ethnocentrism to regional ethno-cultural policies towards Tatars. In particular, one of the republic's cultural duties sounds like promoting the development of the Tatar national culture and the people's culture of the multinational Republic of Tatarstan, its integration into world culture (Belyaev, 2007). Thus, the emphasis is on priorities in relation to the Tatar society which violates the principle of equality of all nationalities which is also enshrined in the Constitution of the Russian Federation. The target of the Cultural Development program in the Republic of Tatarstan for 2015-2019 is given to the support of the Tatar people living outside the republic on the territory of Russia and the Baltic countries (Sergey, 2020). This was a characteristic feature of the republic's ethnocultural policy. One of the tasks of the 2015-2020 Republic of Tatarstan's Socio-Economic Development Program is the development of national education, support for traditional folk culture and cultural autonomy of the nation (Ilinskaya, 2018).

In addition, in the laws of the republic it is possible to record laws on freedom of conscience and on religious associations, which duplicate similar federal laws. However, in the law of the Republic of Tatarstan, there are provisions regarding vakuf assets which indicate the priority position of Islam in the region. There is partial duplication of federal laws in the field of languages. Thus, the law concerning the language of the state of the Republic of Tatarstan and other languages of the Republic of Tatarstan duplicates the law of the Russian Federation on the language of the people of the Russian Federation (Kuznetsov, 2020). At the same time, the laws of the republic establish the status of the Tatar language as the second state language in accordance with Part 2 of Article 69 of the Constitution of the Russian Federation. The State Program of the Republic of Tatarstan for the preservation, study and development of the language of the state of the Republic of Tatarstan and other languages of the Republic of Tatarstan for the years 2004-2019 are used (Sergey, 2020).

\section{Language Support Policy}

The linguistic aspect of the Republic of Tatarstan is the foundation of all ethnocultural policies. The Republic of Tatarstan's law on the state language of the Republic of Tatarstan states: "The language of the states in the Republic of Tatarstan is the same as Tatar and Russian. Articles 10 to 25 regulate the areas of use of both languages which cover the work of the State Council of the Republic of Tatarstan, Cabinet of Ministers of the Republic of Tatarstan, Office The President of the Republic of Tatarstan, the issuance of laws and other statutory regulations in the Republic of Tatarstan holds elections and referendum on the work of local authorities (Zubarevich, 2018). In accordance with Article 7 of the law of the Republic "Concerning the language of the people of the Republic of Tatarstan", a state support program for languages was adopted. The essence of the ethnocultural policy of this region is very clearly expressed by the formulation of one of the program objectives, namely to create conditions for achieving real equality of Tatar and Russian as the language of the Republic of Tatarstan. Furthermore, specific mechanisms for program implementation are determined. While the list of supported languages is first, Tatar (the largest 
number of measures for its preservation and development), then Russian (slightly smaller number) and finally, the representative languages of other people living in the Republic of Tatarstan (less). The distinctive feature of regional ethnocultural policies is their external orientation. So in the same program one can find steps to preserve and develop the Tatar language outside the Republic of Tatarstan (Sergey, 2020).

Even the Cyrillic alphabet used to write not only in Russian charts but also in a modified form in the charts of the Turkish language in Central Asia is the subject of intense controversy. In an attempt to break away from the history of Russian domination and more closely associate itself with the West and Turkey, Tatarstan introduced the Latin alphabet (Kuznetsov, 2020). This problem has many aspects, law, history, language, economy, socio-culture, education. The reason for the transition to the Latin alphabet, according to Saidov Valery as a member of the council in the Republic of Tatarstan, lies in the aspect of foreign policy which includes:

The first reason for trying to switch to the Latin alphabet is that Tatars live in Central Asia and Azerbaijan, while the vocabulary of Tatar and Uzbek languages. equal to $70-80 \%$. If at the same time the same words were written in different letters, then the Tatars would actually use the language of these people (because there was no need to constantly switch from one graph to another) And this threatens the assimilation of the Tatars Another reason for the decision to return Latin script is that many, especially young people are being guided by electronic communication tools adapted to the Latin alphabet. Turkey and Muslims Modern Tatarstan goods are not so widely accepted that the market needs $d$ conquer. The greatest opportunity to gain a foothold somewhere is to develop markets in Central, Southeast Asia and parts of the Muslim world (Interview on 22 July 2020).

The history of the politicization of the alphabet problem began with the suggestion of linguists to add three missing letters to the Cyrillic alphabet which would simplify spelling. But public opinion is now focused on more radical decision making in this area. As a result, several directions of language reform have emerged (Kuznetsov, 2020):

a. Linguists insist on modifying the Cyrillic alphabet;

b. Speaks of the need to restore the "Yanalif" - the Tatar alphabet based on Latin charts, which was used in 1927-1939;

c. Representatives of Muslim scholars proposed to restore Arabic script;

d. It was proposed to adopt a unified Turkish alphabet, approved at the Istanbul Conference of the Turkish Society in 1991;

e. It was proposed to adopt the Latin script, taking into account the modern requirements of the information age (to adopt the Latin "Inalif" alphabet for working on computers).

\section{Support and Interaction with National Cultural Public Associations}

More than 50 national language and cultural society centers are located in the Republic of Tatarstan, the Association of National Cultural Societies of the Republic has been established. To support ethnocultural development, a special educational and cultural institution was opened the People's Friendship House. Practical association since the beginning of its activities declared itself as a public organization that is authoritative and independent. Over the last few years, it has played a large role in the formation of ethnocultural organizations of many people increasing their legal status to national and cultural autonomous societies. The membership of this multinational movement has grown significantly. Currently the Association includes 35 ethnic and cultural organizations. Within the framework of the Association, the Center for Social and Legal 
Assistance for Migrants operates, the art of folklore develops and the cultural identity of the people is enriched. This organization has become one of the most influential civil society institutions in Tatarstan (Sergey, 2020).

In 2007, at the Second Congress of the People of Tatarstan, a decision was approved by it to convert the National Cultural Associations of the Republic of Tatarstan into the People's Assembly of Tatarstan. The Assembly's objective is to promote the national and cultural development of representatives of the peoples living in the region, preserve their ethnocultural identity, strengthen interethnic and inter-religious peace and harmony. Among the tasks of the Assembly, it is necessary to highlight the preservation and development of language, culture and national education, ethnic ways of life, traditional crafts and handicrafts of representatives of the people living in the territory of the Republic of Tatarstan, actively carrying out cultural, educational and informational activities with the aim of developing cultural diversity. and harmony between people of different nationalities, religions and beliefs. Apart from that, it also carries out conflict prevention and prevention on the basis of ethnicity (Izmailov, 2018).

The Republic of Tatarstan pays great attention to the development of national and cultural autonomy so that the function of this institution is quite successful in the regions. According to the law of the republic "On national and cultural autonomy in the Republic of Tatarstan", these associations are entitled to receive the support of the state authorities of Tatarstan and local government bodies necessary to preserve national identity, develop their native language and national culture, create media republican and local masses, receive and distribute information in the mother tongue, follow national traditions and customs, revive and develop artistic folk crafts and crafts, create educational and scientific institutions, cultural institutions and ensure their functioning. In addition, it is desirable to finance national and cultural autonomy activities in the territories either at the expense of the association or the individual itself and by using the republic's budget (Sergey, 2020).

The socio-economic development program of the republic separately establishes the further development of cooperation and regulation of relations with the cultural-national society and autonomy as well as the modernization of cultural and cultural-national autonomy educational activities through support for cultural-national autonomy activities and for the Tatar people living outside the republic for can increase the regulation of national and cultural autonomy laws at the federal and republic level (Zubarevich, 2018). In total, there are about 40 national and cultural autonomies in the region, 16 of which are regional (German, Chuvash, Azerbaijan, Kazakh, Tajik, Uzbek, Greek, Kyrgyz, Jewish, Assyrian, Udmurt, Bashkir, Ukraine, Chechen, Armenian Group, Mordovia) (Sergey, 2020).

\section{Conclusion}

The rise of the situation in the field of inter-ethnic relations can indicate the end of the ethnocentric policy model in the region that sided with the Tatar community in the current conditions of multiculturalism. There are people who are dissatisfied on both sides of the policies taken. At the same time the interests of other ethnic groups in the region have also received less attention such as: Chuvash, Mordovia, Mari, Armenian, etc. This could lead to the radicalization of this ethnic group. In this regard, until now it is necessary to carry out serious discussions on national issues at the federal level so as to avoid conflicts between ethnicities and interest groups. 


\section{References}

Andrew, D. (2015). Languages History for Official Use. Republic Mari-El: Ogon Press.

Belyaev, V. . (2007). Worldview and social behavior of the ruling elite of Tatarstan. Kazan: Social sciences and modernity.

Djokic, A. (2020). The Perspectives of Russia's Soft Power in The Western Balkans Region. RUDN Journal of Political Science, 22(2), 231-244.

Dolzhikova, A. V., \& Moseykina, M. . (2020). Institutions and Educational and Cultural Tools of Migration Policy in Modern Russia. RUDN Journal of Political Science, 22(3), 387-400.

Farida, I., Setiawan, R. (2018). Leadership in Cope With Prostitute in Social Department of Bandar Lampung. International Journal of Social Sciences and Development, 2(1), 1-8.

Gabdrakhmanova, G. . (2008). We are they (attitude towards migrants in the Republic of Tatarstan). Kazan: Sotsiol.

Ilinskaya, S. . (2018). The sea of Russian Culture (Russian Identity and The Concept of Tolerance). RUDN Journal of Political Science, 20(4), 496-505.

Izmailov, I. . (2018). Past history as a factor in national mobilization. Kazan: Kazan Press.

Kuznetsov, I. . (2020). Great Patriotic War in School Literature: Features of Political Socialization of Students. RUDN Journal of Political Science, 22(2), 245-261.

Makarov, G. . (2016). Nagaybaki and the history of civilization. Moscow: Moscow Press.

Markov, R. (2016). Situation of the Kryashens (Book of the Ethnological Monitoring and Early Warning Network). Moscow: Moscow Media.

Sergey, S. (2020). The Republic of Tatarstan: Reduced to a Common Denominator? Russian Politics \& Law, 56(36), 222-235.

Valeev, R. (2005). Tatars at home. Kazan: Kazan Press.

Zubarevich, N. (2018). The Center-Regions Relationship: What Has Changed in Four Years of Crisis? Russian Politics \& Law, 56(36), 208-221. 